\title{
Status and Suggestions of Taiwan Youth Research in the Past 40 Years
}

\author{
Panpan Chen \\ Jinan University \\ Guangzhou, China
}

\author{
Longbiao Huang \\ Guangdong University of Technology \\ Guangzhou, China
}

\begin{abstract}
This paper analyzes articles related to Taiwanese youth among the four most representative young academic journals in China from 1979 to 2018 by using the bibliometric method. In order to understand the current situation and existing problems of Taiwanese youth research, statistical analysis was carried out on the number of papers, research topics, research methods, disciplines, authors and citations. The statistical study shows that Taiwan youth research lacks attention, interdisciplinary and empirical research. Based on the above problems, the study points out further measures to improve Taiwan youth research including paying more attention to Taiwanese youth study, strengthening the multidisciplinary research and increasing empirical research.
\end{abstract}

Keywords-Taiwan youth; the research related to Taiwan youth; the youth journal

\section{INTRODUCTION}

A nation will prosper only when the young thrive. Youth represents the hope and future of a country. Youth research is also a pioneer in sociological research and one of the earliest research fields concerned domestic sociological research. (Feng Xiaotian, 2012) With the continuous development of the economics and society, the thoughts, behaviors and problems faced by the youth groups have also changed, which has attracted the attention of academia. The overall number of articles on youth research is on the rise, accumulating a certain amount of research results. However, it's needed to realize clearly that the study of young people in the mainland accounts for a large proportion of youth research, while that of Taiwan constitutes only a small part, revealing a serious lack of academic attention to the study of Taiwanese youth. In recent years, there have been student movements in Taiwan, such as the "Sunflower Student Movement" in 2014 and the "Anti-Black Box Curriculum Movement" in 2015. On January 1, 1979, the Standing Committee of the National People's Congress issued the "Message to Compatriots in Taiwan", which is an epochmaking moment for the development of cross-strait relations. And on January 1, 2019, the 40th anniversary of the publication of issuing "Message to Compatriots in Taiwan", it plays an important role in promoting the study of Taiwan issue and that of youth to comb the Taiwan's youth research in China over the past 40 years and summarize the development trends and changes in different periods at this special time.

\section{DATA SOURCES AND RESEARCH METHODS}

This study uses the bibliometric method to quantitatively analyze and describe Taiwan's youth research papers by selecting representative youth research academic journals and relying on the China National Knowledge Internet (CNKI) database. In order to narrow the scope of research, this paper selects four representative youth research publications, Youth Studies, Youth Exploration, China Youth Study and Contemporary Youth Research, which have high influence and recognition in the academic circle and can well reflect the overall situation of Taiwanese youth research since 1979. (Feng Xiaotian, 2012) Relying on the retrieval platform of CNKI, literature with "Taiwan" in the title was searched in the four journals from January 1, 1979 to January 1,2019 . Then, on the basis of the search results, the literature with the name of "youth" was searched and non-academic papers were excluded. So the final total number of samples turned out to be 101 . On the basis of the 101 literatures on Taiwanese youth studies, this paper makes a quantitative description and analysis from the perspectives of "paper analysis", "research topic", "research method", "core author group", "subject category" and "citation frequency".

\section{CURRENT SituAtion OF TAIWANESE Youth RESEARCH}

\section{A. Quantitative Analysis of Papers}

Article quantity refers to the number of papers on related topics published in a journal in a certain period of time. It is one of the important indicators for measuring the information transmission ability and output ability of journals, and can reflect the development characteristics and trends of relevant research fields. (Jia Zhiyun, 2008) In order to better embody the development of Taiwanese youth research in the past 40 years, the forty years are divided into four decades, and each decade is a period.

In terms of the total number of articles in the four major youth journals, a total of 18,952 articles were published during the four decades from 1979 to 2019, among which 101 articles on "Taiwan youth" were published, accounting for $0.53 \%$ of the total amount of articles published in the four periodicals in the same period. The small proportion can reflect that Taiwan youth is not the focus of the youth 
research institute in China, meanwhile, academic community is not paying enough attention to Taiwan youth research.

In terms of the total number of articles published in different years, in the first decade, article volume of Taiwan youth research was 13 articles, and the following three decades were followed by 8,19 , and 61 articles. Although the trend of publishing has experienced some fluctuations, the general trend is on the rise. Thus, it can be seen that academic circles are paying more and more attention to the research of Taiwanese youth with high-quality research results constantly being emerging. Among them, the largest number of papers was published in 2016 with 15 related research papers, and 10 in 2014, second only to 2016. The changes in the amount of papers are closely related to the political, economic and social development and changes in Taiwan: the "Sunflower Student Movement" in March 2014 was a social movement caused by the occupation of the "Legislative Yuan" initiated by Taiwanese university students and citizens; at the end of November 2014, the "Nine in One" election in Taiwan was the largest local public official election in history; (Huang Wanyi, 2015) on January 16, 2016, Taiwan's "presidential and legislative" elections, were also known as the "general election" in Taiwan in 2016 (Liu Haichao, 2015)

In regard to the distribution of journal articles, Youth Exploration published 44 articles related to Taiwan youth, which is the highest of the four journals, accounting for $43.6 \%$ of the total sample. The rest are China Youth Study (28, 27.7\%), Contemporary Youth Research (18, 17.8\%), Youth Studies $(11,10.9 \%)$. Over the past 40 years, Youth Exploration has accounted for almost half of the Taiwanese youth research, which is attributed to its long-term development of a special column on youth in Taiwan, Hong Kong and Macao. Meanwhile, "Youth Exploration" is the first of the four journals to publish articles concerning "Taiwan Youth". (See "Table I")

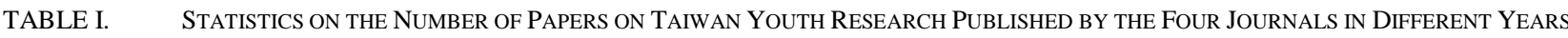

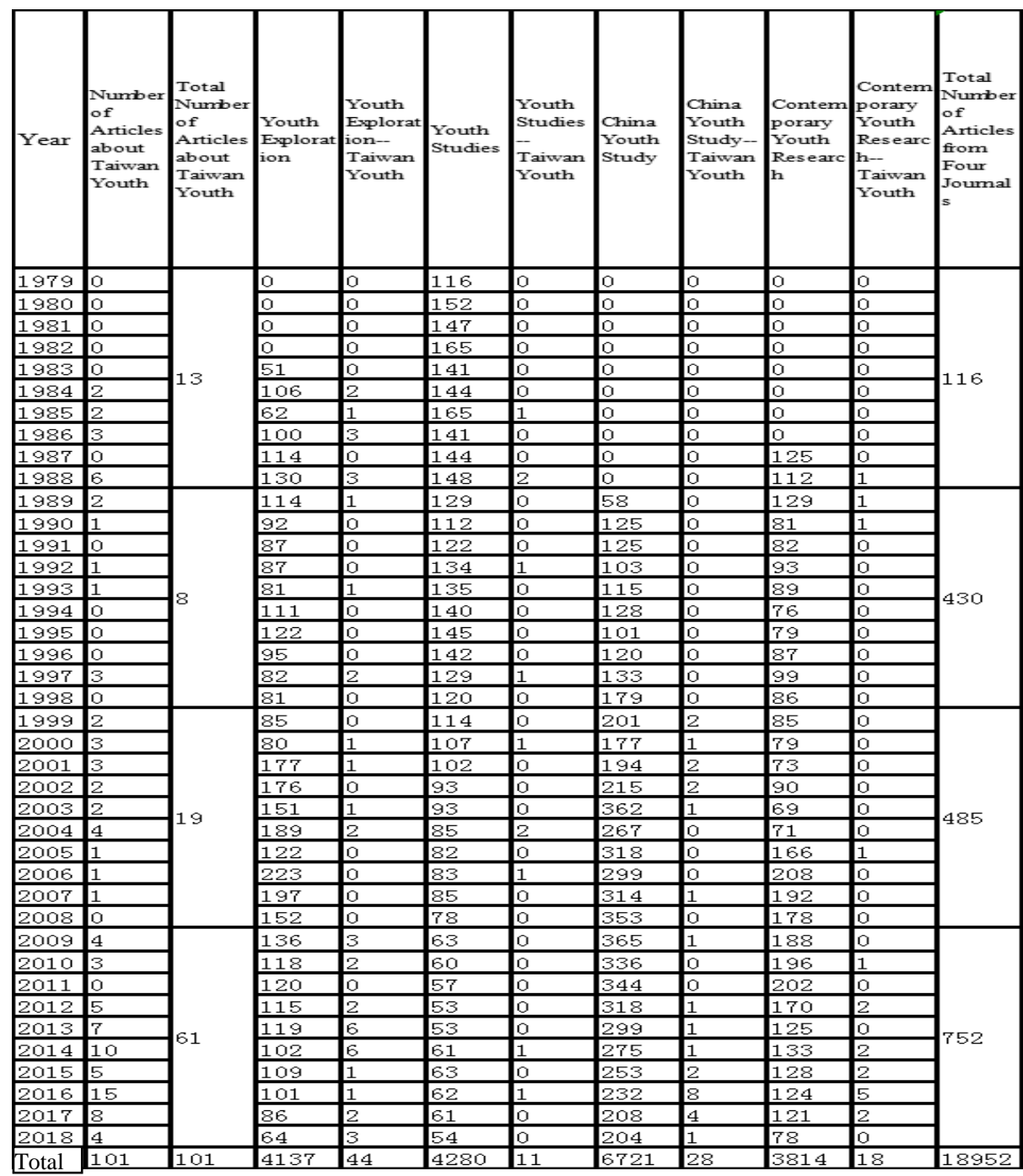




\section{B. Analysis of Research Topics}

The research topics of papers published in journals reflect the focus and main contents of academic circles in this field. In the past 40 years, the research has concentrated on four aspects of the political attitude, political participation, ideological concepts and youth exchanges of Taiwanese youth, with about $10 \%$ in each aspect, accounting for $63.36 \%$ of all Taiwanese youth studies. This reflects that the focus and emphasis of the research on Taiwan youth are in the aspects of political attitude, political participation, ideology, and so on. For the convenience of statistics, in "Table II", research topic with a proportion of less than or equal to $2 \%$ are classified as "other".

TABLE II. OVERALl Distribution OF RESEARCH TOPICS ON TAIWAN YOUTH IN FOUR JOURNALS

\begin{tabular}{|c|l|l|}
\hline Theme & Number of Articles & \multicolumn{1}{|c|}{ Percentage } \\
\hline Political Attitudes & 24 & $23.76 \%$ \\
\hline Political Participation & 17 & $16.83 \%$ \\
\hline Ideological Concepts & 13 & $12.87 \%$ \\
\hline Youth Exchange & 10 & $9.90 \%$ \\
\hline Youth Culture & 5 & $4.95 \%$ \\
\hline Youth Development & 6 & $5.94 \%$ \\
\hline Youth Education & 5 & $4.95 \%$ \\
\hline Youth Marriage & 5 & $4.95 \%$ \\
\hline Social Participation & 4 & $3.96 \%$ \\
\hline Youth Employment & 3 & $2.97 \%$ \\
\hline Youth Tourism & 3 & $2.97 \%$ \\
\hline Other & 6 & $5.94 \%$ \\
\hline
\end{tabular}

In order to understand the changes and differences in the topics of Taiwan youth research in different periods, the author also roughly divided 40 years into four decades.

The results show that in the past four decades, the topic of Taiwan youth research has the following characteristics: First, the proportion of research on political attitudes increased, while that of youth development decreased. The research on political attitudes is $7.69 \%$ in the first decade, $0 \%$ in the second decade, $31.58 \%$ in the third decade, and $27.87 \%$ in the fourth decade, accounting for a quarter of the Taiwan youth studies in the last two decades and becoming the most important topic in the studies. On the contrary, the research on youth development has dropped from the first in the first decade to the negligible level in the fourth decade. Second, research topics show diversification tendency. In the first decade, the research topics were mainly distributed in seven aspects: political attitude, political participation, ideological concepts, youth development, youth culture, youth education, and youth employment. In the third decade, the theme of youth marriage and youth exchanges was added, among which the proportion of youth exchange research rose to third place in the fourth decade, indicating that academic attention to youth exchange research has increased. In the fourth decade, the research topics on social participation, youth tourism and other aspects have also been added, which reveals that research on Taiwanese youth is becoming more and more extensive. (See "Table III") 
TABLE III. Distribution of TAIWAN Youth RESEARCH IN DifFERENT PERIODS

\begin{tabular}{|c|c|c|c|c|c|c|c|c|}
\hline \multirow{2}{*}{ Theme } & \multicolumn{2}{|c|}{$1979-1988$} & \multicolumn{2}{c|}{$1989-1998$} & \multicolumn{2}{c|}{$1999-2008$} & \multicolumn{2}{c|}{$2009-2018$} \\
\cline { 2 - 9 } & $\begin{array}{c}\text { Number of } \\
\text { Articles }\end{array}$ & Percentage & $\begin{array}{c}\text { Number of } \\
\text { Articles }\end{array}$ & Percentage & $\begin{array}{c}\text { Number of } \\
\text { Articles }\end{array}$ & Percentage & $\begin{array}{c}\text { Number of } \\
\text { Articles }\end{array}$ & Percentage \\
\hline Political Attitudes & 1 & $7.69 \%$ & 0 & $0.00 \%$ & 6 & $31.58 \%$ & 17 & $27.87 \%$ \\
\hline Political Participation & 1 & $7.69 \%$ & 2 & $25.00 \%$ & 1 & $5.26 \%$ & 13 & $21.31 \%$ \\
\hline Ideological Concepts & 3 & $23.08 \%$ & 2 & $25.00 \%$ & 3 & $15.79 \%$ & 5 & $8.20 \%$ \\
\hline Youth Exchange & 0 & $0.00 \%$ & 0 & $0.00 \%$ & 2 & $10.53 \%$ & 8 & $13.11 \%$ \\
\hline Youth Culture & 2 & $15.38 \%$ & 1 & $12.50 \%$ & 1 & $5.26 \%$ & 1 & $1.64 \%$ \\
\hline Youth Development & 4 & $30.77 \%$ & 1 & $12.50 \%$ & 0 & $0.00 \%$ & 1 & $1.64 \%$ \\
\hline Youth Education & 1 & $7.69 \%$ & 1 & $12.50 \%$ & 3 & $15.79 \%$ & 0 & $0.00 \%$ \\
\hline Youth Marriage & 0 & $0.00 \%$ & 0 & $0.00 \%$ & 3 & $15.79 \%$ & 2 & $3.28 \%$ \\
\hline Social Participation & 0 & $0.00 \%$ & 0 & $0.00 \%$ & 0 & $0.00 \%$ & 4 & $6.56 \%$ \\
\hline Youth Employment & 1 & $7.69 \%$ & 0 & $0.00 \%$ & 0 & $0.00 \%$ & 2 & $3.28 \%$ \\
\hline Youth Tourism & 0 & $0.00 \%$ & 0 & $0.00 \%$ & 0 & $0.00 \%$ & 3 & $4.92 \%$ \\
\hline Other & 0 & $0.00 \%$ & 1 & $12.50 \%$ & 0 & $0.00 \%$ & 5 & $8.20 \%$ \\
\hline
\end{tabular}

TABLE IV. Distribution OF TAIWAN Youth RESEARCh IN DifFERENT JouRnals

\begin{tabular}{|c|c|c|c|c|c|c|c|c|c|}
\hline \multirow{2}{*}{ Theme } & \multicolumn{2}{|c|}{ Youth Exploration } & \multicolumn{2}{|c|}{ Youth Studies } & \multicolumn{2}{|c|}{ China Youth Study } & \multicolumn{2}{|c|}{$\begin{array}{c}\text { Contemporary Youth } \\
\text { Reasearch }\end{array}$} & \multirow{2}{*}{ Total } \\
\hline & \begin{tabular}{|c|} 
Number of \\
Articles
\end{tabular} & Percentage & \begin{tabular}{|c|} 
Number of \\
Articles \\
\end{tabular} & Percentage & \begin{tabular}{|c|} 
Number of \\
Articles
\end{tabular} & Percentage & $\begin{array}{c}\text { Number of } \\
\text { Articles }\end{array}$ & Percentage & \\
\hline Political Attitudes & 7 & $15.91 \%$ & 4 & $36.36 \%$ & 9 & $32.14 \%$ & 4 & $22.22 \%$ & $23.76 \%$ \\
\hline $\begin{array}{c}\text { Political } \\
\text { Participation }\end{array}$ & 3 & $6.82 \%$ & 1 & $9.09 \%$ & 7 & $25.00 \%$ & 6 & $33.33 \%$ & $16.83 \%$ \\
\hline $\begin{array}{c}\text { Ideological } \\
\text { Concepts }\end{array}$ & 9 & $20.45 \%$ & 3 & $27.27 \%$ & 0 & $0.00 \%$ & 1 & $5.56 \%$ & $12.87 \%$ \\
\hline Youth Exchange & 3 & $6.82 \%$ & 0 & $0.00 \%$ & 4 & $14.29 \%$ & 3 & $16.67 \%$ & $9.90 \%$ \\
\hline $\begin{array}{c}\text { Youth } \\
\text { Development }\end{array}$ & 5 & $11.36 \%$ & 0 & $0.00 \%$ & 0 & $0.00 \%$ & 1 & $5.56 \%$ & $5.94 \%$ \\
\hline Youth Education & 2 & $4.55 \%$ & 1 & $9.09 \%$ & 2 & $7.14 \%$ & 0 & $0.00 \%$ & $4.95 \%$ \\
\hline Youth Marriage & 2 & $4.55 \%$ & 1 & $9.09 \%$ & 1 & $3.57 \%$ & 1 & $5.56 \%$ & $4.95 \%$ \\
\hline Youth Culture & 3 & $6.82 \%$ & 0 & $0.00 \%$ & 1 & $3.57 \%$ & 1 & $5.56 \%$ & $4.95 \%$ \\
\hline $\begin{array}{c}\text { Social } \\
\text { Participation }\end{array}$ & 2 & $4.55 \%$ & 0 & $0.00 \%$ & 1 & $3.57 \%$ & 1 & $5.56 \%$ & $3.96 \%$ \\
\hline $\begin{array}{c}\text { Youth } \\
\text { Employment }\end{array}$ & 3 & $6.82 \%$ & 0 & $0.00 \%$ & 0 & $0.00 \%$ & 0 & $0.00 \%$ & $2.97 \%$ \\
\hline Youth Tourism & 2 & $4.55 \%$ & 0 & $0.00 \%$ & 1 & $3.57 \%$ & 0 & $0.00 \%$ & $2.97 \%$ \\
\hline Other & 3 & $6.82 \%$ & 1 & $9.09 \%$ & 2 & $7.14 \%$ & 0 & $0.00 \%$ & $5.94 \%$ \\
\hline
\end{tabular}

As shown in "Table IV", on the whole, there is little discrepancy in the distribution of research topics among the four journals, but some differences in some research topics. Youth Exploration has the most diversified research on Taiwan youth, mainly focusing on youth's political views and ideology, which accounts for more than $63.63 \%$ of the total, without involving other research topics. However, China Youth Study and Contemporary Youth Research have a large proportion of studies on political perception and political participation, but lack of ideological research. It can be seen that the differences of overall distribution of research topics in the four journals are relatively small, which to some extent reflect the diverse focuses of the journals.

\section{Analysis of Research Methods}

Research methods are tools and means used in the research process, which affect the logic of paper writing, and also reflects an important aspect of the quality and level of academic research. (Feng Xiaotian, 2012) In order to facilitate classification and statistics, this paper divides 
research methods into survey research, field research, experimental research and literature research. (Feng Xiaotian, 1997)

TABLE V. THE OVERALL Distribution OF TAIWANESE YOUTH RESEARCH METHODS IN FOUR JOURNALS

\begin{tabular}{|l|c|c|}
\hline Research Method & $\begin{array}{c}\text { Number of } \\
\text { Articles }\end{array}$ & Percentage \\
\hline Survey Research & 6 & $5.94 \%$ \\
\hline Field Research & 4 & $3.96 \%$ \\
\hline Experimental Research & 0 & $0.00 \%$ \\
\hline Literature Research & 91 & $90.10 \%$ \\
\hline Total & 101 & $100.00 \%$ \\
\hline
\end{tabular}

TABLE VI. Distribution OF TAIWANESE Youth RESEARCH METHODS IN DifFERENT PERIODS

\begin{tabular}{|c|c|c|c|c|c|c|c|c|}
\hline \multirow{3}{*}{ Research Method } & \multicolumn{8}{|c|}{ Different Period } \\
\hline & \multicolumn{2}{|c|}{$1979-1988$} & \multicolumn{2}{|c|}{$1989-1998$} & \multicolumn{2}{|c|}{$1999-2008$} & \multicolumn{2}{|c|}{$2009-2018$} \\
\hline & \begin{tabular}{|c|} 
Number of \\
Articles \\
\end{tabular} & Percentage & \begin{tabular}{|c|} 
Number of \\
Articles \\
\end{tabular} & Percentage & \begin{tabular}{|c|} 
Number of \\
Articles \\
\end{tabular} & Percentage & \begin{tabular}{|c|} 
Number of \\
Articles \\
\end{tabular} & Percentage \\
\hline Survey Research & 0 & $0.00 \%$ & 0 & $0.00 \%$ & 1 & $5.26 \%$ & 5 & $8.20 \%$ \\
\hline Field Research & 0 & $0.00 \%$ & 0 & $0.00 \%$ & 0 & $0.00 \%$ & 4 & $6.56 \%$ \\
\hline Experimental Research & 0 & $0.00 \%$ & 0 & $0.00 \%$ & 0 & $0.00 \%$ & 0 & $0.00 \%$ \\
\hline Literature Research & 13 & $100.00 \%$ & 8 & $100.00 \%$ & 18 & $94.74 \%$ & 52 & $85.25 \%$ \\
\hline
\end{tabular}

The results of "Table VI" show that in the first two decades, only literature study was used in Taiwan youth research. The third decade has one article using survey research, and the fourth decade has nearly $15 \%$ of empirical research. During the past 40 years, the percentage of literature research has dropped from $100 \%$ in the first two
In the overall distribution of Taiwan's youth research methods, as shown in "Table V", literature research with 91 papers accounting for $90.1 \%$ of the total sample size has become the main research method, far higher than the other three research methods. In contrast, the proportion of survey research (6 articles) and field research (4 articles) was very small, accounting for $5.94 \%$ and $3.96 \%$ respectively, which together account for about one-tenth of the total proportion. And the experimental research is none. Conclusion can be drawn that the research methods of Taiwan youth research are mainly literature research and lack of investigation and field research.

TABLE VII. Distribution of TAIWANESE Youth ResEARCH METHOdS IN DifFERENT PubliCATIONS

\begin{tabular}{|c|c|c|c|c|c|c|c|c|}
\hline \multirow{3}{*}{ Research Method } & \multicolumn{8}{|c|}{ Journal } \\
\hline & \multicolumn{2}{|c|}{ Youth Exploration } & \multicolumn{2}{|c|}{ Youth Studies } & \multicolumn{2}{|c|}{ China Youth Study } & \multicolumn{2}{|c|}{$\begin{array}{c}\text { Contemporary Youth } \\
\text { Reasearch }\end{array}$} \\
\hline & $\begin{array}{c}\text { Number of } \\
\text { Articles }\end{array}$ & Percentage & $\begin{array}{c}\text { Number of } \\
\text { Articles }\end{array}$ & Percentage & $\begin{array}{c}\text { Number of } \\
\text { Articles }\end{array}$ & Percentage & $\begin{array}{c}\text { Number of } \\
\text { Articles }\end{array}$ & Percentage \\
\hline Survey Research & 3 & $6.82 \%$ & 3 & $27.27 \%$ & 0 & $0.00 \%$ & 0 & $0.00 \%$ \\
\hline Field Research & 2 & $4.55 \%$ & 0 & $0.00 \%$ & 2 & $7.14 \%$ & 0 & $0.00 \%$ \\
\hline Experimental Research & 0 & $0.00 \%$ & 0 & $0.00 \%$ & 0 & $0.00 \%$ & 0 & $0.00 \%$ \\
\hline Literature Research & 39 & $88.64 \%$ & 8 & $72.73 \%$ & 26 & $92.86 \%$ & 18 & $100.00 \%$ \\
\hline
\end{tabular}


As shown in "Table VII", the four journals use mainly literature research methods. Among them, Contemporary Youth Research adopts $100 \%$ literature research methods, making it the journal with the most frequent use of the research methods. The highest proportion of using survey research methods was by the Youth Studies (27.27\%), accounting for nearly $30 \%$ of the sample documents selected by the journal, followed by Youth Exploration (6.82\%). However, the Taiwanese youth articles published in the other two journals did not use survey research methods. As for field research methods, the largest proportion was China Youth Research $(7.14 \%)$, followed by Youth Exploration $(4.55 \%)$, and the other two journals did not use field research methods.

\section{Analysis of Subject Categories}

Youth research itself is a theoretical research activity involving multidisciplinary participation, (Hu Hongbin, 2013) therefore, Taiwan youth research is no exception. Referring to Meng Li's classification of youth studies, the author divides Taiwan's youth studies into eight aspects: education, talent studies, demography, psychology, politics, sociology, law and economics. (Meng Li, 2004) Using CNKI data platform for screening and analysis, "Table VIII" is obtained. (Hereby explained: since no research articles on law and economics are found, these two items are omitted from "Table VIII") Political science (50.50\%) and sociology $(36.63 \%)$ are the most important disciplines in youth studies, maintaining a relatively stable volume of publications for four decades. This is because, on the one hand, the selected journals belong to the political science and sociology, and on the other hand, the close links lie between Taiwan youth studies and political and social development. Then the research on talent studies accounts for $7.92 \%$. In the last place, pedagogy $(2.97 \%)$, demography $(0.99 \%)$ and psychology $(0.99 \%)$ account for a low proportion of the research, which indicate that some discipline-oriented youth research is relatively weak at present. On the whole, Taiwanese youth research has fairly traditional perspectives and insufficient interdisciplinary research.

TABLE VIII. DISCIPLINARY DISTRIBUTION OF TAIWAN YOUTH RESEARCH IN FOUR JOURNALS IN DIFFERENT PERIODS

\begin{tabular}{|c|c|c|c|c|c|c|}
\hline \multirow{2}{*}{$\begin{array}{c}\text { Subject } \\
\text { Categories }\end{array}$} & \multicolumn{4}{|c|}{ Different Periods } & \multirow{2}{*}{ Total } & \multirow{2}{*}{ Percentage } \\
\hline & $1979-1988$ & $1989-1998$ & $1999-2008$ & $2009-2018$ & & \\
\hline Education & 2 & 1 & 0 & 0 & 3 & $2.97 \%$ \\
\hline $\begin{array}{l}\text { Talent } \\
\text { Science }\end{array}$ & 0 & 0 & 1 & 7 & 8 & $7.92 \%$ \\
\hline $\begin{array}{c}\text { Demograp } \\
\text { hy }\end{array}$ & 1 & 0 & 0 & 0 & 1 & $0.99 \%$ \\
\hline $\begin{array}{c}\text { Psycholog } \\
\mathrm{y}\end{array}$ & 0 & 0 & 1 & 0 & 1 & $0.99 \%$ \\
\hline Politics & 8 & 2 & 8 & 33 & 51 & $50.50 \%$ \\
\hline Sociology & 2 & 5 & 9 & 21 & 37 & $36.63 \%$ \\
\hline
\end{tabular}

\section{E. Core Author Group Analysis}

Authors are the main body of academic research, and their scientific research ability directly determines the quality of research results. Therefore, core authors are the backbone force to promote the development of research field and the key factor to reflect the research level and development level of academic journals. (Zhong Wenjuan, 2012) Lotka pointed out that there is a certain relationship between the number of researchers and the number of papers, that is, in a mature research field, the number of authors writing " $n$ " papers is about " $1 / \mathrm{n}^{2}$ " of the number of authors writing a paper, and the number of authors writing one paper accounts for about $60 \%$ of the total number of authors. (Wang Zhaoguang, $\mathrm{He}$ Jianyu, 2004) Based on CNKI, the author analyzed the research articles of Taiwanese youth published in four major journals from 1978 to 2018. Among 101 articles, 74 were the first authors. Among them, 57 were the authors of one article, accounting for $77.03 \%$ of the total number of authors, which was higher than $60 \%$ of Lotka's law. However, the number of authors who published two or four articles accounted for $1 / 6.3,1 / 9.5$, and $1 / 28.5$ of the number of authors who published one article, respectively (for comparison, the fraction is expressed in the form that the numerator and denominator are reduced and the numerator is 1$)$, which is smaller than the corresponding value in Lotka's law $(1 / 4,1 / 9$ and $1 / 16$ respectively), indicating that the research on youth in Taiwan is not yet mature and lacks long-term highyielding researchers. (See "Table IX") 
TABLE IX. Distribution OF THE AUTHOR'S VOLUME OF PUBLICATIONS

\begin{tabular}{|l|l|l|}
\hline $\begin{array}{l}\text { Number of } \\
\text { Published } \\
\text { papers }\end{array}$ & $\begin{array}{l}\text { Number of } \\
\text { authors }\end{array}$ & $\begin{array}{l}\text { Accounted for } \\
\text { the total number } \\
\text { of authors }\end{array}$ \\
\hline 1 & 57 & $77.03 \%$ \\
\hline 2 & 9 & $12.16 \%$ \\
\hline 3 & 6 & $8.11 \%$ \\
\hline 4 & 2 & $2.70 \%$ \\
\hline Total & 74 & $100.00 \%$ \\
\hline
\end{tabular}

According to Price's Law, the number of papers published by the core author of the same topic "m" should meet $" \mathrm{~m}=0.749 * \sqrt{n \max }$ " (nmax refers to the number of papers published by the most productive author). The core authors mentioned in this article refer to authors who published 2 or more articles (See "Table X"). According to statistics, there are 17 core authors, accounting for $22.97 \%$ of the total number of authors and $43.57 \%$ of the total number of articles, which is far from the standard of $10 \%$ of authors and $50 \%$ of the number of articles published by Price's law. This shows that in the past 40 years, the authors in the field of youth research in Taiwan have been widely distributed, but lack of continuous researchers. The research ability of Taiwan youth research field is still immature and has not yet formed an influential core group of authors.

TABLE X. CORE AUthor Group IN Four PeriodicAls

\begin{tabular}{|c|c|c|c|c|}
\hline $\begin{array}{c}\text { Serial } \\
\text { number }\end{array}$ & author & Institution & \begin{tabular}{|c|}
$\begin{array}{c}\text { Number of } \\
\text { Published } \\
\text { Paper }\end{array}$ \\
\end{tabular} & $\begin{array}{l}\text { Times } \\
\text { Cited }\end{array}$ \\
\hline 1 & Ai Mingjiang & Taiwan Research Institute of Xiamen University & 4 & 20 \\
\hline 2 & Zhu Feng & $\begin{array}{c}\text { Industrial and Commercial College of Hebei } \\
\text { University }\end{array}$ & 4 & 6 \\
\hline 3 & Wu Leyang & Taiwan Research Institute of Xiamen University & 3 & 20 \\
\hline 4 & Su Songxing & $\begin{array}{c}\text { Taiwanese, Hong Kong and Macao Youth } \\
\text { Research Laboratory, Shanghai East Asia } \\
\text { Research Institute }\end{array}$ & 3 & 19 \\
\hline 5 & $\begin{array}{l}\text { Zeng } \\
\text { Shengcong }\end{array}$ & $\begin{array}{c}\text { School of Economics and Law, Fujian Normal } \\
\text { University }\end{array}$ & 3 & 16 \\
\hline 6 & Tang Dezhong & Taiwan Research Institute of Ningbo University & 3 & 15 \\
\hline 7 & Zhou Zhi & $\begin{array}{c}\text { Taiwan Affairs Office of Yichang City, Hubei } \\
\text { Province }\end{array}$ & 3 & 13 \\
\hline 8 & $\begin{array}{l}\text { Zhang } \\
\text { Gongxian }\end{array}$ & Political Department of Jinan Military Region & 3 & 1 \\
\hline 9 & Li Long & $\begin{array}{c}\text { Department of Political Science, Renmin } \\
\text { University of China }\end{array}$ & 2 & 18 \\
\hline 10 & Liu Lingbin & $\begin{array}{c}\text { Institute of Modern Taiwan Research, Fujian } \\
\text { Academy of Social Sciences }\end{array}$ & 2 & 15 \\
\hline 11 & Huang Jichao & Taiwan Research Institute of Xiamen University & 2 & 9 \\
\hline 12 & Fang Yi & China Youth Research Journal & 2 & 8 \\
\hline 13 & Lin Shunhua & $\begin{array}{l}\text { Taiwan Research Department, School of } \\
\text { Economics and Law, Fujian Normal University }\end{array}$ & 2 & 8 \\
\hline 14 & Tang Hua & Taiwan Research Institute of Xiamen University & 2 & 6 \\
\hline 15 & Liu Yaqiong & College of Marxism, Renmin University of China & 2 & 3 \\
\hline 16 & Sun Xuan & $\begin{array}{l}\text { Document Information Center of Fujian } \\
\text { Academy of Social Sciences }\end{array}$ & 2 & 1 \\
\hline 17 & Yang Xiaoping & Guangzhou League School & 2 & 0 \\
\hline
\end{tabular}


As shown in "Table $\mathrm{X}$ ", the authors with the largest number of publications are Ai Mingjiang from Xiamen University and Zhu Feng from the Business School of Hebei University, each of which published four related articles. The 17 authors are all mainland scholars from mainland universities or research institutions, none of whom is from Taiwanese institutions. This may be because Taiwanese thematic papers are too localized to be published in international journals, which leads Taiwanese scholars to pay less attention to Taiwanese youth research. Besides, eight authors are from relevant institutions in Fujian Province, accounting for $47 \%$ of the total number of authors, owing to the proximity of Fujian province to Taiwan and its geographical advantages to do research.

\section{F. Citation Frequency Analysis}

The citation frequency of journal articles is an important basis for judging the influence of articles. High-frequency cited papers in academia means high quality and high attention. Based on bibliometric method, this paper analyzes the indexes such as highly cited papers and authors of four journals in four decades. (Wang Peipei, 2010) According to the analysis of CNKI statistical platform, the top ten highly cited papers of four major journals in the past 40 years are summarized in "Table XI".

TABLE XI. CORE Author Group of TAIWAN Youth Research IN Four JOURNALS IN THE PAST 40 YeARS

\begin{tabular}{|c|c|c|c|c|c|c|}
\hline Rank & Title & Author & Journal & Published Time & Citation & Downloads \\
\hline 1 & $\begin{array}{l}\text { Current Situation of Taiwan Youth's National } \\
\text { Identity and Suggestions }\end{array}$ & Chen Xing & China Youth Study & $2016-2-5$ & 16 & 1292 \\
\hline 2 & $\begin{array}{l}\text { Political Consciousness and Political } \\
\text { Participation of Taiwanese College Students } \\
\text { in Shanghai }\end{array}$ & Dong Xiaoping & Youth Studies & 2006-10-30 & 15 & 651 \\
\hline 3 & $\begin{array}{l}\text { Political Identity of Taiwan Youth and the } \\
\text { Peacefil Development of Cross-strait } \\
\text { Relations }\end{array}$ & Liu Lingbin & |Youth Exploration & 2016-1-14 & 14 & 2380 \\
\hline 4 & $\begin{array}{l}\text { Analysis of Political Apathy among Taiwan } \\
\text { Youth and Its Influence Factors }\end{array}$ & Wu Leyang & China Youth Study & $2013-11-5$ & 14 & 77 \\
\hline 5 & $\begin{array}{l}\text { The political Identity and the Trend of } \\
\text { Taiwanese Young Voters }\end{array}$ & Tang Dezhong, Wang An & Youth Studies & $2004-2-29$ & 12 & 650 \\
\hline 6 & $\begin{array}{l}\text { A Comparative Analysis of the Ideological } \\
\text { concepts of Cross-straits youth }\end{array}$ & Zhou Zhi & Youth Studies & 2004-2-29 & 11 & 468 \\
\hline 7 & $\begin{array}{l}\text { A Comparative Analysis of the Lack of } \\
\text { Chinese Identity among Hong Kong and } \\
\text { Taiwan Youth }\end{array}$ & Li Long & China Youth Study & $2015-7-5$ & 10 & 846 \\
\hline 8 & $\begin{array}{l}\text { The Analysis of the Status and Influence of } \\
\text { Taiwan Youth's national identity -- } \\
\text { Combination of the Political Effect and } \\
\text { Evaluation of Young Students' "Anti-Black } \\
\text { Box Curriculum Movement" }\end{array}$ & Liu Haichao & China Youth Study & $2016-2-5$ & 9 & 810 \\
\hline 9 & $\begin{array}{l}\text { Three-dimensional Analysis of the National } \\
\text { Identity of Hong Kong and Taiwan Youth }\end{array}$ & Li Long & China Youth Study & $2016-2-5$ & 8 & 923 \\
\hline 10 & $\begin{array}{l}\text { Populist Youth Movement in Hong Kong and } \\
\text { Taiwan since the Sunflower Movement: } \\
\text { Characteristics and Countermeasures }\end{array}$ & Gu Xuguang, Tian Feng & China Youth Study & $2016-6-5$ & 8 & 971 \\
\hline
\end{tabular}

It can be drawn from "Table XI" that among the four journals in the past 40 years, the highest cited literature on Taiwanese youth research was written by Chen Xing, "Current Situation of Taiwan Youth's National Identity and Suggestions", published in China Youth Study with 16 citations, while the most cited one on young people in the Mainland is "Psychological Analysis of Mobile Phone Addiction in College Students" in the Contemporary Youth Research published by Han Dengliang and Qi Zhifei with 295 citations. Secondly, the total citation frequency of the 
top 10 is 117 , with an average cited frequency of 11.7 , which is far lower than the average citations of research papers on mainland youth. To sum up, the citations of Taiwanese youth research articles are much lower than those of mainland youth, reflecting from the side that Taiwanese youth research is less concerned than mainland youth. The top 10 most frequently cited articles are from China Youth Study (6), Youth Studies (3) and Youth Exploration (1). The two journals, China Youth Study and Youth Studies, which are highly cited, do not have the largest number of articles published in the four journals, but they are both CSSCI source journals and core journals of Peking University. Their professionalism and authority are recognized by the academic circles, thus affecting the quotation of articles.

\section{CONCLUSION}

Over the past 40 years, the mainland academia have actively explored the issue of Taiwan youth and achieved numerous research results. On the one hand, the focus on Taiwan youth research continues to grow. From the analysis of the papers, the number of articles on Taiwan youth research has increased significantly. On the other hand, Taiwan's youth research is increasingly diversified. Through the analysis of research topics, the content of Taiwan youth research has been expanding. Undeniably, the academic circles have published a number of research results with theoretical and practical guiding value, which have made important contributions to enriching the Taiwanese youth research. However, there are still some deficiencies in the current research on Taiwan youth, as follows:

There is insufficient attention paid to Taiwanese youth research. It can be seen from the analysis of the papers that the number of research papers on Taiwan youth is generally on the rise, with academic circles paying more and more attention to the research on Taiwan youth. However, from the perspective of research proportion, the number of papers on Taiwan youth research only accounts for a small proportion $(0.53 \%)$ of the total number of articles published in the four journals in the same period. From the citation frequency, the highest cited amount of Taiwanese youth research literature is 16 , which is far lower than that of Mainland youth research (295). It can be concluded that Taiwanese youth is not the focus of the youth research. Meanwhile, academic circles pay less attention to Taiwanese youth research, which lags far behind the development of the reality needs.

Interdisciplinary research is insufficient. At present, the existing research perspective of Taiwan youth is more traditional, focusing on political science and sociology. There are few studies from other disciplines, and interdisciplinary studies are even rarer. For one thing, multidisciplinary participation is an inherent requirement of youth research. Youth research itself is a theoretical activity with multidisciplinary participation, so Taiwan youth research is no exception. Therefore, the research methods and thinking of a single subject are not comprehensive and profound. For another, multidisciplinary participation is the realistic demand of youth research. Especially with the development of Taiwan's economy and society, the complexity and comprehensiveness of Taiwan's youth issues have determined that Taiwan's youth research must effectively use the research perspectives and results of other disciplines to conduct multidisciplinary, multi-angle, and multi-level research, and to further promote and enrich Taiwan's youth research.

Empirical research is relatively lacking. Through sorting out the articles of four major youth academic journals in the past 40 years, it is found that the most important research method of Taiwan youth research is literature research (90.1\%), which means that there is a lack of empirical data support in Taiwan youth research. Researchers have not obtained concrete and vivid understanding from directly approaching the research objects. Hence it is difficult to understand the reality of Taiwan youth in a deep, true, objective and comprehensive way, which makes the article less reliable and less instructive. When a large amount of research is established without the support of empirical data, it is not conducive to the long-term development of the research field, and needs to attract the attention and vigilance of the academic community.

In order to further improve the level of research on Taiwan youth, the following suggestions are put forward for future research:

More attention should be paid to research on Taiwan's youth. The contrast between the active youth movement in Taiwan and the lack of youth research in Taiwan is a wakeup call. No matter young researchers, youth research institutions or academic journals of youth research, they should pay more attention to Taiwan youth research, and arouse the attention of academia and society to Taiwan youth research by setting up research projects, investing research funds and setting up columns about Taiwan youth research. In this way, they can start from the situation and new problems faced by Taiwan youth and based on the actual situation of Taiwan to make suggestions for the better growth and development of Taiwan youth.

The multidisciplinary research orientation of Taiwan youth research should be strengthened. Multidisciplinary participation is the inherent requirement and practical need of youth research. Only through multidisciplinary participation can we grasp Taiwan youth research in essence. This puts forward higher requirements for researchers. Researchers need to actively draw lessons from the research results and methods of related disciplines and explore ways and means of interdisciplinary research. Starting with the perspective and methods of youth research in the mainland, interdisciplinary development of youth research can then be constantly promoted in Taiwan.

Empirical research needs more attention. To carry out Taiwan youth research, it is necessary not only to pay attention to the social hotspots and problems related to Taiwan youth, but also to explore the group characteristics and development status of Taiwanese youth through real events. Therefore, Taiwan youth research should be based on the field research methods of sociology and anthropology to conduct investigations and collect first-hand data. The collected empirical data and materials are used to support the 
relevant research on Taiwan youth, so as to enhance the scientific and practical guiding significance of research.

\section{REFERENCES}

[1] Feng Xiaotian.Content Analysis of 2408 Papers in Four Youth Research Journals [J].Youth Studies, 2012.

[2] Wanghailou. Message to Compatriots in Taiwan has been Published for 40 years. [EB/OL]

http://theory.people.com.cn/n1/2019/0101/c409499-30497688.html

[3] Jia Zhiyun. Does Number of Papers Carried in a Journal Affect lts Impact Factor? [J]. Chinese Journal of Scientific and Technical Periodicals, 2008.

[4] Huang Wanyi. The Political Participation of Young Taiwanese Seen From the "Nine in One" Election [J]. China Youth Study, 2015.

[5] Liu Haichao. The Analysis of the Status and Influence of Taiwan Youth's national identity - Combination of the Political Effect and Evaluation of Young Students' "Anti-Black Box Curriculum Movement" [J]. China Youth Study, 2015.

[6] Feng Xiaotian. Social Investigation Method or Social Research Method? - One of the Sociological Approaches [J]. Sociological Studies, 1997.

[7] Hu Hongbin. Review and Outlook: The Domestic Youth Research Trends (2002-2011) — Based on Quantitative Analysis of the Five Youth Research Academic Journal [J]. Contemporary Youth Research, 2013

[8] Meng Li. A Quantitative Analysis of the Research Status of Youth in China in the Past Ten Years [J]. Youth Studies, 2004.

[9] Zhong Wenjuan. Evaluation About the Core Authors Based on Price Law and Comprehensive Index Method - Take Journal of Library Development as an Example [J]. Science and Technology, 2012.

[10] Wang Zhaoguang, He Jianyu. The Associational Revolution in China — The Map of Chinese Association [J]. Zhejiang Journal, 2004.

[11] Wang Peipei. Analysis on Focus, Trend and Core - Authors Group of Youth Studies: A Stdudy Based on the CSSCI [J]. Youth Studies, 2010. 